\title{
Rat Spermatogenesis Damage in Intermittent Hypobaric Hypoxia and the Protective Role of Melatonin. I Cauda Epididymal Spermatozoa
}

\author{
Daño en la Espermatogénesis de Rata en Hipoxia Hipobárica Intermitente \\ y el Papel Protector de la Melatonina. I Espermatozoides de la Cauda Epididimaria
}

"Ricardo Hartley; * Rodrigo Castro-Sánchez; **Benito Ramos-Gonzalez \& *Eduardo Bustos-Obregón

HARTLEY, R.; CASTRO-SÁNCHEZ, R.; RAMOS-GONZALEZ, B. \& BUSTOS-OBREGÓN, E. Rat spermatogenesis damage in intermittent hypobaric hypoxia and the protective role of melatonin. I Cauda epididymal spermatozoa. Int. J. Morphol., 27(4):12751284, 2009.

SUMMARY: At present it is not clear if male fertility is affected by intermittent hypobaric hypoxia (IHH). This is an important issue since a large human population works over 3000 masl. This study analyzes epididymal sperm, in adult Sprague Dawley rats after five cycles of IHH (7 days exposure to 4200 masl in a hypobaric chamber / 7 days at 500 masl). The animals were separated into groups of 8 , one group was exposed to hypoxia ( 7 days), and the others to IHH for one to five cycles. Controls (500 masl) were examined at the beginning and at the end of the 70 experimental days. A duplicate set of rats treated with melatonin (supposedly protecting from hypoxia) was also examined, as were their controls, injected with $0,03 \%$ ethanol (melatonin solvent). Epididymal sperm parameters, were evaluated. Damage caused by IHH increases with time. Sperm counts drop, while sperm chromatin swelling, DNA instability (metachromasia with acridine orange epifluorescence) and comet $(+)$ tests increase. Melatonin counteracts all this damage, possibly due to its high efficiency as a reactive oxygen species scavenger. In conclusion, IHH exposure damages sperm quality and therefore male reproductive function.

KEY WORDS: Sperm quality; Intermittent hypobaric hypoxia; Melatonin protection.

\section{INTRODUCTION}

As altitude increases, both the barometric pressure and the partially inspired oxygen pressure decreases and generates hypoxia (Chinn \& Hannon, 1970; Gamboa, 1998). Several reports have documented that hypobaric hypoxia is responsible for alterations in male reproductive function. Due to the increase in the number of male workers at high altitude, the study of the effects of hypobaric hypoxia on spermatogenesis has acquired great interest in the last 20 years. Its mechanism of action -implicated in fertility reduction- has not been accurately established, reason for which the problem needs to be further reviewed and studied, particularly for cases of intermittent hypoxia, which is the most common form of human exposure to hypoxia in mining activities in the north of Chile. Moreover, a recent publication by Siqués \& Brito (2001) refers to intermittent high altitude labors as a new epidemiological situation of global health concern.
It is well known that hypoxia exerts an inhibiting effect on all dividing cell populations (Kim \& Han, 1969; Check et al., 1969). For this reason, it is possible to state that the cell populations involved in the gametogenic process might be susceptible to this condition, although the current evidence on the matter is as yet inconclusive.

Under hypoxic conditions, an increase in reactive oxygen species is registered. Melatonin is a powerful free radical scavenging antioxidant, highly specific against lipid peroxidation -an activity that increases considerably in hypoxic situations-. This hormone could have a possible protective effect on testicles of mice under hypoxia.

In the testis, spermatogenesis takes place in the tubular compartment, and steroidogenesis in the interstitial

\footnotetext{
" Laboratory of Biology of Reproduction, Program of Anatomy and Developmental Biology, ICBM, University of Chile, Medical School, Chile.

**Andrology Laboratory, Pathology Department, UANL, Medical School, Monterrey, México.
} 
compartment. Despite being anatomically separated, both compartments are closely connected with one another in a paracrine manner. The integrity of both compartments is necessary for a quantitative and qualitatively normal sperm production (Brinkworth \& Handelsam, 1997). Spermatogenesis is a complex process of cell proliferation and differentiation that occurs in the seminiferous tubules (Sokol et al., 1994). The seminiferous epithelium is a complex and highly dynamic tissue in which germ cells proliferate, undergo meiosis, and differentiate into spermatozoa (Timmons et al., 2002). This process consists of three significant events: differentiation of germ cells, chromosomal recombination during meiosis of the spermatocytes after spermatogonial mitotic proliferation, and the dramatic morphological changes the haploid germ cells undergo in order to mature into spermatozoa. The Sertoli cells provide an ideal microenvironment for the proper proliferation and differentiation of germ cells. This process is regulated by hormonal stimuli that are recognized by receptors located both in Sertoli and Leydig cells (Bizarro et al., 2003). Many factors (like toxicants, temperature, hypoxia) can affect any of the cells that participate individually in this process, but due to the great interdependence among them, the damage will become extensive to the whole tissue set (Sobarzo \& BustosObregon, 2000).

Due to the great distance of oxygen diffusion, the luminal region of the seminiferous tubules has a hypoxic atmosphere compared with the basal regions. Additionally, the high proliferative activity of the germinal epithelium suggests noticeable oxygen consumption, with the consequent reduction in local oxygen concentration.

The slow adaptation responses to low oxygen levels in the whole organism include an increase in the erythrocyte production due to erythropoietin, a hormone produced by the kidney. The erythropoietin gene transcription is regulated by the Hypoxia-Inducible Factor 1 (HIF-1), a transcriptional activator. The nature of the oxygen sensor that causes the greater expression of HIF-1 is still unknown. Besides regulating the erythropoietin gene, HIF-1 activates the transcription of several other genes (approximately 70) in a coordinated manner, and these codified proteins help the cells to respond to hypoxia (Lodish et al., 2005). Recent studies indicate that hypoxia stimulates the release of reactive oxygen species (ROS) from mitochondria, regulating the transcriptional response generated in conditions of hypoxia, which in turn can induce physiological alterations leading to oxidative stress (Agarwal \& Said, 2005; Hsu et al., 1997; Ping-Chi et al., 1998, Golden et al., 1999; El-Missiry, 2000). Among free radicals ROS stand out; the most important being the superoxide anion, the hydroxyl ion and hydrogen peroxide. Under normal physiological conditions, there is a balance between pro-oxidant molecules and antioxidants (Engel et al., 1999). When the formation of ROS surpasses the antioxidant capacity of the intracellular protective mechanisms, the probability of oxidative damage on important cell biomolecules (such as proteins, carbohydrates, lipids and nucleic acids) increases (Pande \& Flora, 2002; El-Missiry; Ercal et al., 1996). In the sperm cell, the antioxidant systems are present in the cytoplasm and in the seminal plasma, preventing the accumulation of ROS, thus preserving the sperm function.

Oxidative stress due to an excessive production of ROS is associated with defects in sperm function (Wang et al., 2003). Some studies indicate that $20 \%$ of the cases of male infertility are due to sperm damage caused by ROS (Bhardwaj et al., 2000). High levels of ROS are detected in $25 \%$ of patients diagnosed with clinical infertility (Engel et al.). Almost $40 \%$ of infertile patients show an abnormal increase in ROS levels in seminal plasma. An increase in the incidence of oligospermia has been reported in patients who also present an increase in ROS levels in seminal plasma (Whittington et al., 1999). In addition, ROS can induce damage in the cell DNA and apoptosis in spermatozoa (Agarwal \& Said).

The plasma membrane is one of the places where cell damage by ROS can be induced. Its constituent polyunsaturated fatty acids may undergo lipid peroxidation, which leads to degenerative cell alterations (Bhardwaj et al.; El-sokkary et al., 2003). The damage in the integrity of the plasma membrane will increase its permeability, leading to the inactivity of certain enzymatic systems, structural damage to the DNA, and even to cell death (Koksal et al., 2003; Engel et al.). Spermatozoa are highly sensitive to ROS action due to the great amount of polyunsaturated fatty acids that compose their plasma membrane (Golden et al.) and that confer them greater flexibility. Therefore, ROS syntheses induced by the exposure to hypoxia -as well as the lipid peroxidation these molecules induce- play a very important role in the pathogenicity of testicular and sperm damage (Othman et al., 2001). Furthermore, spermatozoa posses a reduced cytoplasm (due to its morphology), thus limiting the amount of cytoplasmic antioxidant molecules for selfprotection against the oxidative action of ROS (Golden et al.). Therefore, supplementing with exogenous antioxidant agents could be of great relevance for the prevention and treatment of oxidative damages in seminal plasma and spermatozoa.

Melatonin is a neuroendocrine hormone synthesized by the pineal gland, mainly during the dark phase of the circadian cycle (Awney et al., 2002; Blumenthal et al., 1997). 
Numerous reports have documented the protective action of melatonin in several models of cell oxidative stress (HiroAki \& Hai-Wang, 1996). These properties of melatonin significantly reduce tissue damage provoked by ROS generation in vivo and in vitro. In addition, melatonin has shown to be an effective protector of nuclear DNA, and proteins and lipids that constitute cell membranes against the attack of ROS (Lena \& Subramanian, 2003; El-Missiry; Kim et al., 1998). Melatonin has a better antioxidant effect than glutathione against the highly toxic hydroxyl radical; it also has more effective antioxidant properties than tocopherols (El-Missiry). Due to its lipophilic and hydrophilic properties (that allow it to cross cell membranes easily) melatonin has the capacity to provide antioxidant protection to most subcellular compartments (Lena \& Subramanian; Hiro-Aki \& Hai-Wang). In addition, it can cross morpho-physiological barriers such as the blood-testis barrier, thus protecting most cells from oxidative damage (Kim et al.). Melatonin stimulates the activity of the enzymes that metabolize ROS (El-sokkary et al.) and has effects on the testicular metabolism in adult rats, which suggests a possible role of the hormone in the modulation of the testicular function (Hemieda, 2003).

Melatonin is highly specific against lipid peroxidation, a phenomenon that increases remarkably as a cell response to hypoxia.

The present study analyzes the damage of the quality of the chromatin of epididymal spermatozoa, as well as the role of ROS in intermittent hypobaric hypoxia and the protective function of the antioxidant melatonin, in an effort to characterize and counteract the reproductive deleterious effects of hypoxia.

\section{MATERIAL AND METHOD}

For this study, 144 healthy, sexually mature (2-3 months old) male Sprague Dawley rats were obtained from the animal room of the School of Medicine, University of Chile. They were kept under a 12:12 light-dark regime at 22 $\pm 2{ }^{\circ} \mathrm{C}$ and fed with pelleted food and water ad libitum. Rats were separated into 18 groups of 8 individuals each. The experimental scheme considered a two-step design, with one incorporating melatonin treatment in the drinking water (10 $\mathrm{mg} / \mathrm{kg}$ body weight). The following groups were included: Controls 1 and 2, maintained in conditions of normoxia (Santiago of Chile, barometric pressure of $710 \mathrm{~mm} \mathrm{Hg}, 540$ meters above sea level (m.a.s.l.), PO2=148,6 mm Hg) and sacrificed at the beginning and at the end of the experiment, respectively; and Groups 1, 2, 3, 4 and 5, exposed to intermittent hypoxia ( $\mathrm{IHH}$, simulating $4200 \mathrm{~m}$.a.s.1.) in cycles of $7 \mathrm{~d}: 7 \mathrm{~d}$ hypoxia/normoxia ( 1 cycle $=14$ days $)$ simulated by a hypobaric chamber. The groups were exposed to " $n$ " cycles, with " $n$ " determined according to the number of the respective group. One extra group was exposed only to 7 days of $\mathrm{HH}$, without an alternating period of normoxia. For the melatonin treatment, 2 control groups consuming ethanol $0,03 \%$ (vehicle for melatonin) in the drinking water were added. (see Table I).

Once the experimentation intervals were completed for each group, a blood sample was obtained from each individual and the percentage of microhematocrit and reticulocytes was calculated in a blood smear dyed with cresyl blue and read under a light microscope (400X) until counting 100 cells.

Table I. Experimental dessign. 1cycle=7days hypoxia / 7 days normoxia. IHH:Intermittent Hypobaric Hypoxia (simulating 4200 masl). Day 0 denotes the beginning of expossure.

\begin{tabular}{lcc}
\hline Group & $\begin{array}{c}\text { Cycles IHH (1 cycle=7 days } \\
\text { hypoxia / }\end{array}$ days nomoxia & $\begin{array}{r}\text { Days at the moment of the sacrifice } \\
\text { (day } 0=\text { experience started }\end{array}$ \\
\hline Control 1 & - & 0 \\
Control 2 & - & 70 \\
7 days & 7 days hypoxia & 7 \\
1 cycle & 1 & 14 \\
2 cycle & 2 & 28 \\
3 cycle & 3 & 42 \\
4 cycle & 4 & 56 \\
5 cycle & 5 & 70 \\
\hline
\end{tabular}


Rats were sacrificed according to the protocol accepted by the Ethics Committee of the School of Medicine, University of Chile. Epididymides were excised postmortem and the following analyses were performed: epididymal weight (grams), sperm count (after macerating each cauda epididymis, the sperm counted in the resulting fluid was determined with a Mackler chamber under microscope, sperm morphology, chromatin packing (sodium thioglycolate assay) (Fornés \& Bustos-Obregón, 1994), DNA stability (acridine orange test, AO) (Tejada et al., 1984) and Comet assay (Ostling \& Johanson, 1984).

Means and standard deviations were calculated for every parameter and an analysis of variance (ANOVA) was performed using the $\mathrm{F}$ test. The $\mathrm{F}$ value was calculated with the statistical software Stata 8.0 and statistical significance was established when $\mathrm{p}<0.05$.

\section{RESULTS}

Blood analysis. Hematocrit values increased significantly after 7 days of exposure to hypoxia, returning to normality soon after cessation of the treatment (Table II). Reticulocyte percentages also increased progressively along with duration of exposure to hypoxia, reaching a maximum value on the second cycle and then declining to values similar to the control group (Table II). Melatonin attenuates these variations, with values similar among treated and control groups when used concomitantly with hypoxia. Generally speaking, the behavior of blood variables express an expected physiological response against hypobaric intermittent hypoxia.

Semen analysis. Sperm count (Fig. 1). Counting showed a significant reduction in all experimental groups, except in the group exposed to hypoxia for seven days where there was only a small, non-significant reduction. A slight recovery can be noticed in group 2; however, after that, the reduction in sperm count is progressive until it reaches the minimum values in group 5. Groups that were given melatonin tend to reach higher values in all experimental groups, with differences that do not reach statistical significance. When comparing these results against the control, a tendency to progressive reduction is observed, being statistically significant only for groups 4 and 5.

Comet Assay (Fig. 2). It has been observed, that the higher the number of cycles of exposure to hypoxia, the more cells present damaged chromatin (Comet percentage increases), being statistically significant for cycles 3, 4 and 5. IHH mainly damages the nuclei of epididymal sperm and consequently correlates with sperm head anomalies and positive Comet frequency. Such an increase is minor, but it maintains its tendency in groups that received melatonin in drinking water becoming significant in groups 3, 4 and 5 . The percentage of positive Comet spermatocytes turned out to be significantly lower in groups 4 and 5 of melatoninconsuming rats when compared to those that did not consume melatonin. The overall rate of teratozoospermia follows the same pattern than that of the Comet assay results.

Sperm morphology. Sperm morphology during epididymal transit shows the highest frequency of morphological anomalies on the flagellum, while intermittent hypoxia makes head anomalies more predominant. These anomalies are reduced in $50 \%$ by the action of melatonin which renders the tail anomalies rate equal to the control values. It must be mentioned that amongst tail anomalies, a rounded aspect of the distal portion of the intermediate segment was recurrently observed, alteration which can possibly be caused by an agglutination of mitochondria in this region, related perhaps to sperm apoptosis.

DNA stability (Fig. 3). According to the AO test, a greater instability in sperm chromatin is noticeable in groups exposed to a larger number of exposure cycles to hypoxia,

Table II. Hematocrit after IHH. It tends to increase progressively in the groups with and without melatonin. In the group 7 days there is a marked increase only without melatonin. Percentage of reticulocytes after IHH. Melatonin avoids partially the peaks found in goups without melatonin. Reticulocytes tend to increase with more cycles and then (3rd cycle) lowers to control like values.

\begin{tabular}{|c|c|c|c|c|c|c|}
\hline & \multicolumn{3}{|c|}{ Hematocrit } & \multicolumn{3}{|c|}{ Reticulocyte \% } \\
\hline Group & Without melatonin & Melatonin & Ethanol & Without melatonin & Melatonin & Ethanol \\
\hline Control 1 & 35.4 & 43.6 & 43.9 & 2.1 & 2.3 & 1.8 \\
\hline Control 2 & 46.0 & 48.2 & 44.2 & 1.6 & 1.3 & 1.8 \\
\hline 7 Days & $46.0^{*}$ & 339.0 & - & 2.9 & 3.3 & - \\
\hline 1 Cycle & 37.7 & 43.6 & - & 4.1 & 3.1 & - \\
\hline 2 Cycle & 39.5 & 45.6 & - & $5.9^{* \#}$ & $2.6^{\#}$ & - \\
\hline 3 Cycle & 43.1 & 47.2 & - & 5.1 & 3.4 & - \\
\hline 4 Cycle & 44.0 & 44.2 & - & 3.6 & 2.5 & - \\
\hline 5 Cycle & $46.6^{*}$ & 47.2 & - & 3.0 & 2.2 & - \\
\hline
\end{tabular}

1278 


\section{SPERM COUNT $10^{6}$ / mg EPIDIDYMIS}

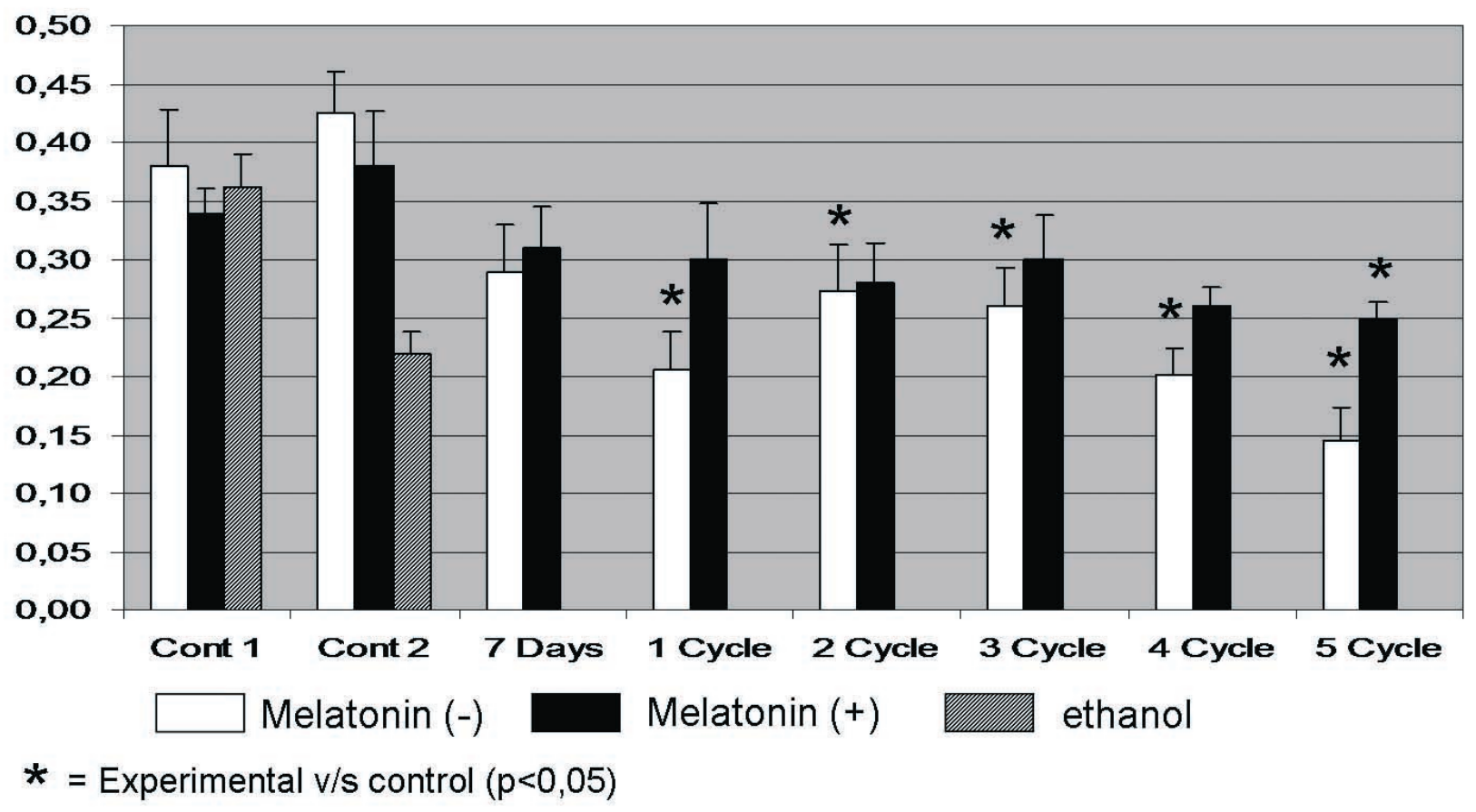

Fig. 1. IHH reduces significantly the sperm count in all groups without melatonin, except in 7 days. Melatonin groups tend to decrease but not significantly compared to melatonin (-) in each cycle.

\section{SPERMATOCYTE COMET ASSAY (+) (\%)}

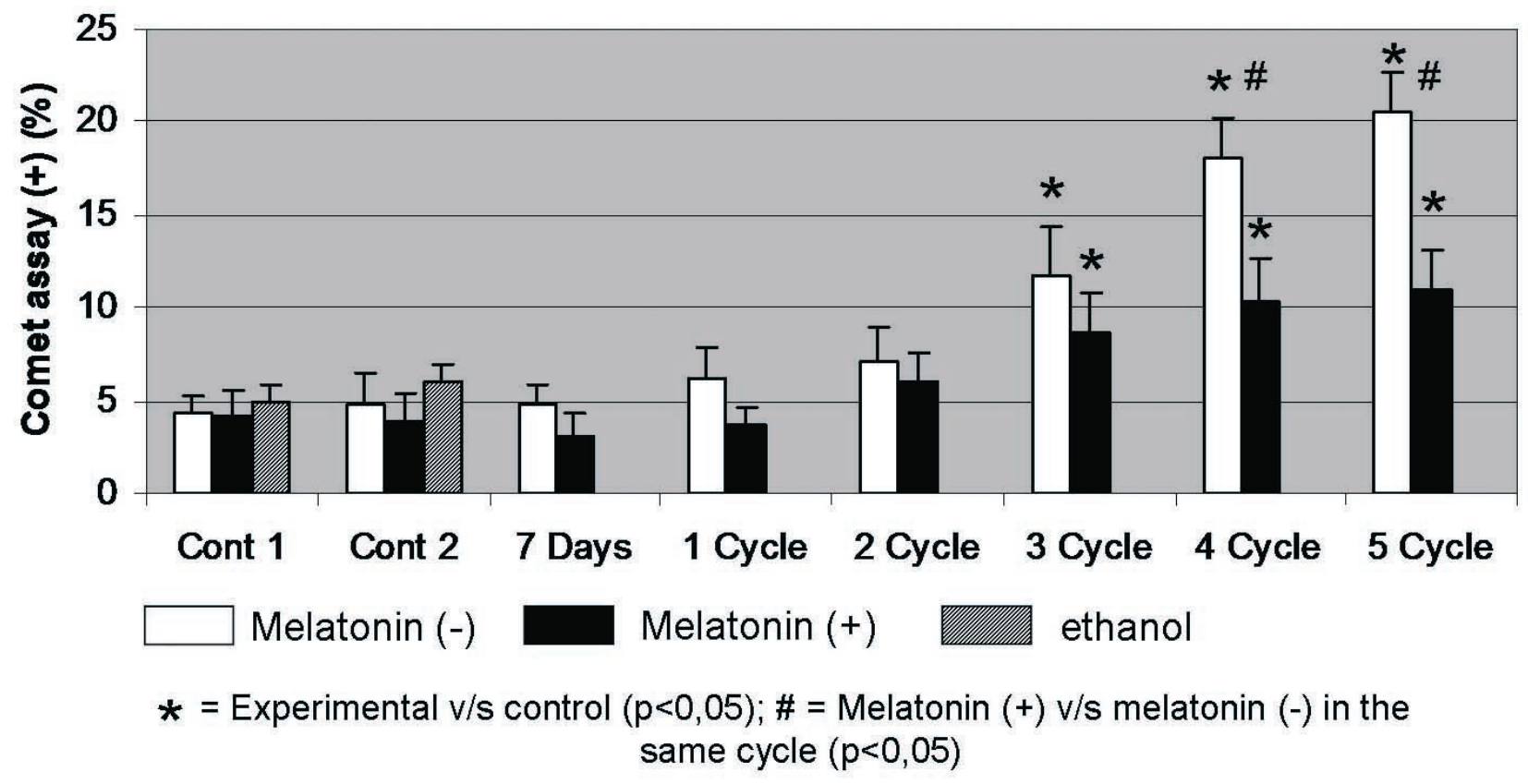

Fig. 2. Percentage of comet (+) test with and without melatonin tend to increase progressively, being significant by the 3rd cycle onwards. 


\section{ACRIDINE ORANGE TEST (\% METACHROMASIA)}

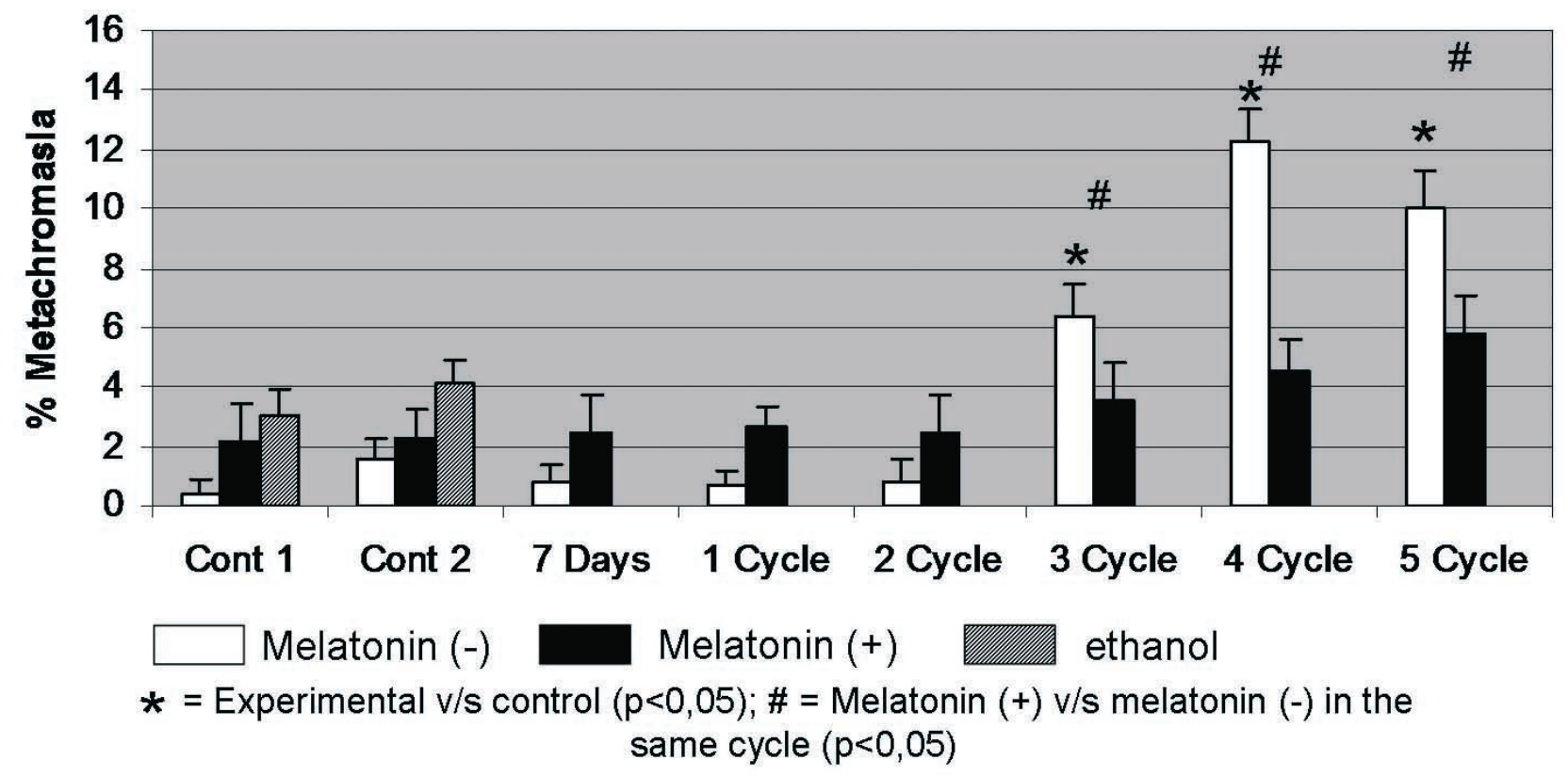

Fig. 3. The percentage of metachromasia of cauda epididymal spermatozoa nuclei does not changes in the first and second cycles, but it increases significantly from the 3rd cycle onwards, where melatonin diminishes these values.

\section{CHROMATIN SWELLING (\%)}

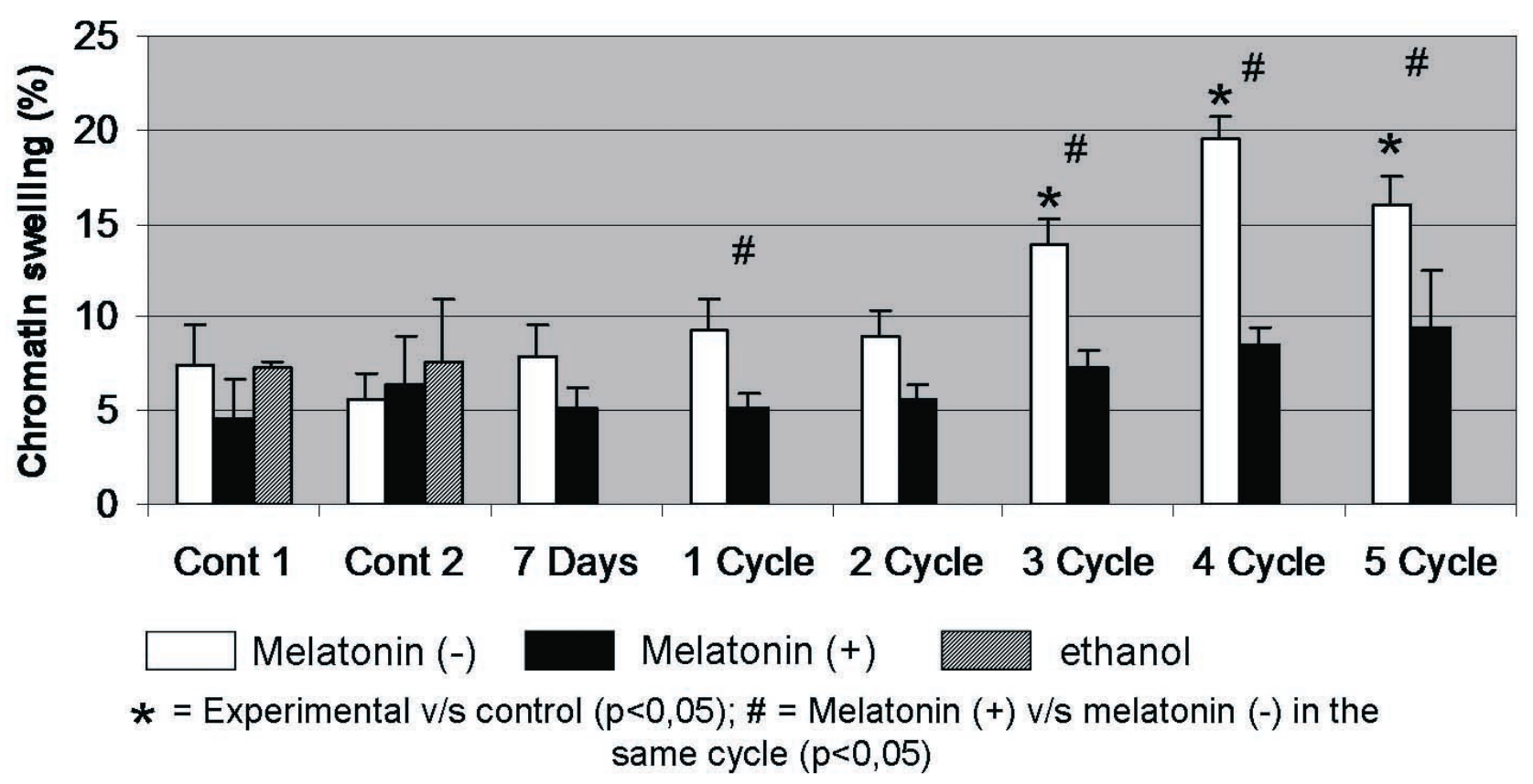

Fig. 4. Chromatin of cauda epididymal spermatozoa nuclei swelling increases progresively with number of cycles of exposure. However this increasse is significantly lower in cycles $1,3,4$ and 5 , treated with melatonin. 
reaching statistical significance from group 3 onwards and being group 4 the one that showed the greatest instability. Groups that were given melatonin showed only a tendency to DNA instability, increasing when exposure to hypoxia increased but without reaching any statistical significance. However, melatonin consumption generated DNA stability with statistical significance when compared to no melatonin consumption in groups 3, 4 and 5.

The percentage of sperm with non-compact chromatin (Fig. 4) tended to increase with hypoxia, but melatonin consumption partially recovered their normal values. Teratozoospermia rates behave similarly. In conclusion, hypoxia alters the quality of sperm chromatin, a situation that is partially improved by melatonin.

\section{DISCUSSION}

Although reductions in reproductive parameters have already been associated with the exposure to hypoxic environments (Bustos-Obregón et al., 2006), there is uncertainty regarding the mechanism of action in the case of intermittent exposure to this factor in a similar situation to that faced by mineworkers at high altitudes.

The proposed experimental model helps, in part, to determine the ways in which this noxa negatively affects the male factor, determining a reduction in fertility. It should be mentioned that exposure to hypobaric chamber in simulated hypoxia differs from natural hypoxic conditions in the altitude where temperature and environmental radiation, among other factors, should be considered.

The physiological response to hypoxia, observed in the experimental groups as an abrupt increase in haematological variables, such as percentages of microhematocrit and reticulocytes, returning rapidly to the basal values (control), were expected as an adaptation to hypoxia (Bustos-Obregón \& Vargas, 2009)

As a result of the techniques applied in this study, it is possible to relate both morphological and physiological aspects of the spermatogenesis, assigning a direct effect on cellular DNA in the loss of fertile capacity (seminal quality) of the gametes.

The production of ROS, in response to hypoxia and the lipoperoxidation of the membranes that its accumulation produces, has a direct relationship between the lesions produced by the hypoxia and the time or number of cycles of exposure (Bustos-Obregón \& Vargas). Consequently, in groups with the most number of cycles of exposure to hypoxia, an alteration of the spermatic variables was observed, determining increases in the swelling of the chromatin, DNA instability and the Comet (+) test, all of which manifest a lesion at a nuclear or genetic level in the gametes, which in addition to the reduction in the sperm count in the tail of the epididimys, determine a reduction of the fertile potential. The repercussion at a gametic level, caused by an exposure to hypoxia, mentioned before by Othman et al., would be explained by Garrido et al., (2004), based on the reduced antioxidant capacity of the spermatozoa, due to their small amount of cytoplasm, which leads to a reduced capacity to respond when confronted to an accumulation of ROS (Engel et al.).

Oxidative stress affects genomic integrity of the spermatozoa, even with rupture of DNA strands (Shen et al., 1999), as denoted by metachomatic sperm nuclei found in our work in exposed mice. Damage to the plasma membrane can end in sperm apoptosis and a lower number of fertilizing gametes (Koksal et al.).

The alternant exposure to a hypoxic and a normoxic environment permits a certain recovery or attenuation of the general lesions caused during the hypoxia. This contrasts with the experimental models which consider a chronic exposure to hypoxia without alternation with normoxia, in which case the lesions are progressive and sustained (García, 1977).

The mechanism of action involved in the spermatic lesions due to exposure to hypoxic environments is not clear. Nevertheless, given the effective protection given by melatonin, a strong scavenging agent of free radicals, it is possible to propose that an excess of ROS, produced during hypoxia, plays a fundamental role in this process. It seems, therefore that the mechanism of ROS action should be explored in more details in future works.

The sensitivity to hypoxia of populations of cells in active replication, added to the fact that the testicular tissue is already under a relative hypoxia (due to the difficulty of an adequate diffusion of oxygen to the adluminal compartment), make of the seminiferous epithelium a candidate to suffer lesions by exposure to these environments. Furthermore, the reduced amount of the spermatozoid's cytoplasm is also a predisposing factor to peroxidative damage by accumulation of ROS, because of the small quantity of antioxidant molecules contained in it, which determines a defective gametogenesis. The lesions generated by $\mathrm{IHH}$ progressively increase, in relation to the number of cycles of exposure. Regarding the spermatic variables considered, there is an increase in chromatin swelling, 
DNA instability and Comet (+) test, while there is a reduction in sperm count and normal morphology. Melatonin partially counteracts these lesions. The protective role shown by
Melatonin and its antioxidant characteristics, lead us to believe that ROS actively participate in producing such lesions, and consequently in reducing male fertility.

HARTLEY, R.; CASTRO-SÁNCHEZ, R.; RAMOS-GONZALEZ, B. \& BUSTOS-OBREGÓN, E. Daño en la espermatogénesis de rata en hipoxia hipobárica intermitente y el papel protector de la melatonina. I Espermatozoides de la cauda epididimaria. Int. J. Morphol., 27(4):1275-1284, 2009.

RESUMEN: En la actualidad no está claro si la fertilidad masculina se ve afectada por la hipoxia hipobárica intermitente (HHI). Esta es una cuestión importante, ya que una gran población humana trabaja a más de 3000 metros sobre el nivel del mar (msnm). Este estudio analiza los espermatozoides del epidídimo, en ratas Sprague Dawley adultas, después de cinco ciclos de HHI (7 días de exposición a $4200 \mathrm{msnm}$ en una cámara hipobárica / 7 días a $500 \mathrm{msnm}$ ). Los animales fueron separados en grupos de 8, un grupo fue expuesto a la hipoxia (7 días), y los otros a HHI de uno a cinco ciclos. Los controles (500 msnm) se examinaron al comienzo y al final de los 70 días de experimentación. Un grupo duplicado de ratas tratadas con melatonina (supuestamente protegiendo de la hipoxia) también fue examinado, al igual que los controles, inyectados con 0,03\% de etanol (solvente de melatonina). Los parámetros espermáticos del epidídimo fueron evaluados. Los daños causados por la HHI aumentaron con el tiempo. Se evaluó el conteo espermático en gota, mientras la cromatina espermática esta hinchada, la inestabilidad del ADN (metacromasia epifluorescente con naranjo de acridina) y la prueba de aumento (+) de cometas. La melatonina neutralizó todo el daño, posiblemente debido a su alta eficacia como un eliminador de especies reactivas de oxígeno. En conclusión, la exposición a HHI daña la calidad espermática y por lo tanto la función reproductora masculina.

PALABRAS CLAVE: Calidad espermática; Hipoxia hipobárica intermitente; Protección de la melatonina.

\section{REFERENCES}

Agarwal, A. \& Said, T. Oxidative stress, DNA damage and apoptosis in male infertility: a clinical approach. Brit. J. Urol. Int., 95:503-7, 2005.

Awney, H.; Attih, A.; Habib, S. \& Mostafa, M. Effect of melatonin on the production of microsomal hydrogen peroxide and cytochrome P-450 content in rat treated with aflatoxin B1. Toxicology, 172:143-8, 2002.

Bhardwaj, A.; Verma, A.; Majumdar, S. \& Khanduja, K. Status of vitamin E and reduced glutathione in semen of oligozoospermic and azoospermic patients. Asian J. Androl., 2:225-8, 2000.

Bizarro, P.; Acevedo, S.; Niño-Cabrera, G.; Mussali-Galante, P.; Pasos, F.; Avila-Costa, M. \& Fortoul, T. Ultrastructural modifications in the mitochondrion of mouse Sertoli cells after inhalation of lead, cadmium or lead-cadmium mixture. Reprod. Toxicol., 17:561-6, 2003.

Blumenthal, G.; Kohn, M. \& Portier, C. A mathematical model of production, distribution, and metabolism of melatonin in mammalian systems. Toxicol. Appl. Pharmacol., 147:83-92, 1997.

Brinkworth, M. \& Handelsam, D. Occupational and environmental influences on male fertility. In: Andrology
Male Reproductive Health and Dysfunction. Nieschlag, E. \& Behre, H. M. (eds). Berlin, Springer-Verlag, 1997. pp. 25-54.

Bustos-Obregón, E.; Esveile, C.; Contreras, J.; Maurer, I. \& Sarabia, L. Effects of chronic simulated hypobaric hypoxia on mouse spermatogenesis. Int. J. Morphol., 24:481-8, 2006.

Bustos-Obregón, E. \& Vargas, A. Ibuprofen and melatonin Project Mouse testis in continuous or intermittent hypoxia. J. Androl., 30(suppl):89, 2009.

Check, D.; Graystone, J. \& Rowe, R. Hipoxia and malnutrition in newborrats: effects on RNA, DNA and protein in tissues. Am. J. Physiol., 217:642, 1969.

Chinn, K. \& Hannon, J. Effects of Diet and Altitude on the Body Composition of Rats. J. Nutr., 100:732-8, 1970.

El-Missiry, M. Prophylactic effect of melatonin on leadinduced inhibition of heme biosynthesis and deterioration of antioxidants systems in male rats. $J$. Biochem. Mol. Toxicol., 14:57-62, 2000.

El-sokkary, G.; Kamel, E. \& Reiter, R. Prophylactic effect of melatonin in reducing lead-induced neurotoxicity in the rat. Cell. Mol. Biol. Lett., 8:461-70, 2003. 
HARTLEY, R.; CASTRO-SÁNCHEZ, R.; RAMOS-GONZALEZ, B. \& BUSTOS-OBREGÓN, E. Rat spermatogenesis damage in intermittent hypobaric hypoxia and the protective role of melatonin. I Cauda epididymal spermatozoa. Int. J. Morphol., 27(4):1275-1284, 2009.

Engel, S.; Schreiner, T. \& Petzoldt, R. Lipid peroxidation in human spermatozoa and maintenance of progressive sperm motility. Andrologia, 31:17-22, 1999.

Ercal, N.; Treeratphan, P.; Hammond, T.; Matthews, R.; Grannemann, N. \& Spitz, D. In vivo indices of oxidative stress in lead-exposed c57bl/6 mice are reduced by treatment with meso - 2, 3 - dimercaptosuccinic acid or N-acetylcysteine. Free Radic. Biol. Med., 21:157-61, 1996.

Fornés, M. \& Bustos-Obregón, E. Study of nuclear decondensation of the rat spermatozoa by reducing agents epidydimal transit. Andrologia, 26:87-92, 1994.

Gamboa, R. Fisiología y fisiopatología cardiovascular durante la exposición aguda a la altura. Acta Andina, 7:3546, 1998.

García, M. A. Efecto de la exposición a una altura de 4.500 $m$ sobre la morfología y función testicular en ratas. México D. F., XII Congreso Latinoamericano de Ciencias Fisiológicas, 1977.

Garrido, N.; Mosaeguer, M.; Simon, C.; Pellicer, A. \& Remohi, J. Pro-oxidative and anti-oxidative imbalance in human semen and its relation with male fertility. Asian J. Androl., 6:59-65, 2004.

Golden, A.; Moline, J. \& Bar-chama, N. Male reproduction and environmental and occupational exposures: a review of epidemiologic methods. Salud Pública Mex., 41:93$105,1999$.

Hemieda, F. Melatonin produced metabolic changes in testis and did not prevent indomethacin-induced testicular lipid peroxidation in adult rat. Indian J. Exp. Biol., 41:220-4, 2003.

Hiro-aki, Y. \& Hai-wang, T. Antagonistic effect of melatonin against cyanide-induced seizures and acute lethality in mice. Toxicol. Lett., 87:19-24, 1996.

Hsu, P.; Liu, M.; Hsu, C.; Chen, L. \& Guo, Y. Lead exposure causes generation of reactive oxygen species and functional impairment in the rat sperm. Toxicology, 122:133-43, 1997.

Kim, J. \& Han, S. Studies of hipoxia V. Effects of anoxia on developing connective tissue cells in rats. Anat. Rec., 165:531-41, 1969.

Kim, K.; Base, S.; Lee, O.; Bae, M.; Lee, M. \& Parck, B.
Insuline-like growth factor II induced by hypoxia my contribute to angiogenesis of human hepatocellular carcinoma. Cancer Res., 58:348-1, 1998.

Koksal, I.; Usta, M.; Orhan, I.; Abbasoglu, S. \& Kadioglu, A. Potential role of reactive oxygen species on testicular pathology associated with infertility. Asian J. Androl., 5:95-9, 2003.

Lena, P. \& Subramanian, P. Evaluation of the antiperoxidative effects of melatonin in ammonium acetate-treated Wistar rats. Pol. J. Pharmacol., 55:10316, 2003.

Lodish, H.; Berk, A.; Matsudaira, P.; Kaiser, C.; Krieger, M.; Scott, M. \& Zipursky, S. Biología Celular y Molecular. $5^{\mathrm{a}}$ edition. Buenos Aires, Medica Panamericana Press, 2005.

Ostling, O. \& Johanson, K. Microelectroforetic study of radiation-induced DNA damage in individual mammalian cells. Biochem. Biophys. Res. Common., 288:47-63, 1984.

Othman, A.; El-Missiry, M. \& Amer, M. The protective action of melatonin on indomethacin-induced gastric and testicular oxidative stress in rats. Redox Rep., 6:173-7, 2001.

Pande, M. \& Flora, S. Lead induced oxidative damage and its response to combined administration of a-lipoic acid and succimers in rats. Toxicology, 177:187-96, 2002.

Ping-Chi, H.; Ming-Yie, L.; Chao-Chin, H.; Lih-yuh, C. \& Yueliang, L. Effects of vitamin $\mathrm{E}$ and/or $\mathrm{C}$ on reactive oxygen species-related lead toxicity in the rat sperm. Toxicology, 128:169-79, 1998.

Shen, H. M.; China, S. E. \& Ong, C. N. Evaluation of oxidative DNA damage in human sperm and its association with male infertility. J. Androl., 20:718-23, 1999.

Siqués, P. \& Brito, J. Trabajo a gran altura intermitente: Nueva situación epidemiológica. Iquique, Chile, Universidad Arturo Prat Press, 2001.

Sobarzo, C. \& Bustos-Obregón, E. Acute effect of parathion of the seminiferous epithelium of immature mice. Rev. Chil. Anat., 18:61-8, 2000.

Sokol, R.; Okuda, H.; Nagler, H. \& Berman, N. Lead exposure in vivo alters the fertility potential of sperm in vitro. Toxicol. Appl. Pharmacol., 124:310-6, 1994. 
HARTLEY, R.; CASTRO-SÁNCHEZ, R.; RAMOS-GONZALEZ, B. \& BUSTOS-OBREGóN, E. Rat spermatogenesis damage in intermittent hypobaric hypoxia and the protective role of melatonin. I Cauda epididymal spermatozoa. Int. J. Morphol., 27(4):1275-1284, 2009.

Tejada, R.; Cameron, J.; Norman, A.; Marik, J. \& Friedman, S. A test for the practical evaluation of male fertility by acridine orange (AO) fluorescence. Fertil. Steril. 42(1):87-91, 1984.

Timmons, P. M.; Rigby, P. W. \& Poirier, F. The murine seminiferous epithelial cycle is pre-figured in the Sertoli cells of the embryonic testis. Development, 129(3):63547, 2002.

Wang, X.; Sharma, R.; Sikka, S.; Thomas, A.; Falcone, T. \& Agarwal, A. Oxidative stress in associated with increased apoptosis leading to spermatozoa DNA damage in patients with male factor infertility. Fertil. Steril., 80:5315, 2003.

Whittington, K.; Harrison, S.; Williams, K.; Day, J.; Mclaughlin, E.; Hull, M. \& Ford, C. Reactive Oxygen Species (ROS) production and the outcome of diagnostic test of sperm function. Int. J. Androl., 22:236-42, 1999.

\section{Correspondence to:} Eduardo Bustos-Obregón Independencia 1027 POBox 70061. Santiago, CHILE

Phone 56-2-9786473

Fax 56-2-7237488

Email: ebustos@med.uchile.cl

Received: 07-09-2009

Accepted: 12-11-2009 